\title{
EKSPERIMENTASI MODEL PEMBELAJARAN KOOPERATIF \\ TIPE NUMBERED HEADS TOGETHER (NHT) DAN STUDENT \\ TEAMS ACHIEVEMENT DIVISIONS (STAD) DITINJAU \\ DARI KEINGINTAHUAN DAN GAYA KOGNITIF \\ PESERTA DIDIK SMP DI KABUPATEN BLORA
}

\author{
Agung Putra Wijaya, Mardiyana, Suyono \\ Program Studi Magister Pendidikan Matematika \\ Program Pascasarjana Universitas Sebelas Maret
}

\begin{abstract}
The purposes of this study are to know the different effect of each category of learning model, curiosity, and cognitive style, also their interaction towards mathematics achievement. This study is a quasi experimental research with $2 \times 3 \times 2$ factorial design. The population is all students of junior high school in Blora. Sampling was done by stratified cluster random technique. The instruments used to collect data are test of prior knowledge in mathematics, curiosity questionnaire, cognitive style test (GEFT), and mathematics achievement test. The testing of hypothesis uses three-way analysis of variance with unequal cell.

The testing of hypothesis concludes that (1) There is a different effect between each category of learning model. (2) There is a different effect among each category of curiosity. (3) There is a different effect among each category of cognitive style. (4) There is an interaction between learning model and curiosity towards mathematics achievement. (5) There is an interaction between learning model and cognitive style towards mathematics achievement. (6) There is an interaction between curiosity and cognitive style towards mathematics achievement. (7) There is an interaction among learning model, curiosity, and cognitive style towards mathematics achievement.
\end{abstract}

Keywords: NHT, STAD, Curiosity, Cognitive Style, Mathematics Achievement

\section{PENDAHULUAN}

Sejalan dengan paradigma baru pendidikan di Indonesia yang lebih menekankan pada peserta didik sebagai individu yang memiliki potensi untuk belajar dan berkembang, pemerintah mendorong pelaksanaan inovasi pembelajaran matematika yang didasarkan pada teori belajar konstruktivisme untuk jenjang pendidikan dasar dan menengah. Inovasi pembelajaran tersebut diharapkan mampu memberikan tantangan belajar sesuai kemampuan peserta didik dengan memperhatikan perbedaan individual peserta didik. 
Dengan demikian, proses pembelajaran akan berpusat pada peserta didik dan guru hanya bertindak sebagai fasilitator pembelajaran.

Hanya saja, pelaksanaan inovasi pembelajaran tersebut mengalami banyak hambatan, termasuk pada pembelajaran matematika di SMP yang ada di Kabupaten Blora. Belum optimalnya pelaksanaan inovasi pembelajaran tersebut diduga berdampak pada rendahnya prestasi belajar matematika peserta didik SMP di Kabupaten Blora. Berdasarkan laporan hasil Ujian Nasional tahun pelajaran 2009/2010, rerata prestasi belajar matematika peserta didik SMP di Kabupaten Blora (6,53) lebih rendah dibandingkan rerata prestasi belajar matematika peserta didik SMP di tingkat Propinsi Jawa Tengah $(6,73)$ maupun nasional (7,29). Dari 10.006 peserta ujian nasional SMP di Kabupaten Blora pada tahun pelajaran 2009/2010, terdapat 3.779 peserta didik (sekitar 37,77\%) yang memperoleh nilai matematika di bawah rerata. Selain itu, mata pelajaran matematika bagi peserta didik SMP di Kabupaten Blora ini merupakan mata pelajaran penyumbang angka ketidaklulusan terbesar kedua setelah mata pelajaran bahasa inggris.

Selain itu, analisis daya serap hasil Ujian Nasional tahun pelajaran 2009/2010 terhadap tiga kemampuan yang berkaitan dengan materi pokok persamaan garis lurus, yakni menentukan gradien garis lurus dengan persamaan $a x+b y+c=0(a, b, c$ bilangan bulat selain satu), menentukan persamaan garis pada sebuah grafik, dan menentukan grafik dari persamaan suatu garis menunjukkan bahwa penguasaan konsep persamaan garis lurus oleh peserta didik SMP di Kabupaten Blora masih rendah.

Kesulitan yang dialami oleh peserta didik SMP di Kabupaten Blora dalam menyelesaikan soal-soal yang berkaitan dengan konsep persamaan garis lurus dimungkinkan karena jarang dilakukannya penyelesaian soal secara kooperatif atau diskusi saat pembelajaran berlangsung. Sebagian besar guru matematika masih menerapkan model pembelajaran konvensional. Selama kegiatan pembelajaran guru aktif menyampaikan informasi di depan kelas, sedangkan peserta didik hanya menyimak, mencatat, dan mengerjakan latihan soal. Kondisi ini menyebabkan tujuan pembelajaran cenderung tidak tercapai secara optimal.

Agar tujuan pembelajaran tercapai secara optimal, guru harus cermat dalam memilih suatu model pembelajaran yang akan diterapkan. Di antara banyak model pembelajaran, 
salah satu model pembelajaran inovatif yang dapat diterapkan adalah model pembelajaran kooperatif. Melalui model pembelajaran kooperatif, peserta didik secara aktif mengkonstruksi pemahamannya melalui diskusi kelompok. Peserta didik secara kooperatif mengkonsultasikan kesulitan yang dialaminya kepada peserta didik lain sehingga sangat dimungkinkan bagi peserta didik untuk mengatasi kesulitan-kesulitan tersebut.

Selain model pembelajaran, terdapat faktor-faktor lain yang mempengaruhi prestasi belajar matematika yang juga perlu mendapat perhatian dari guru, diantaranya adalah keingintahuan dan gaya kognitif. Dengan mengetahui perbedaan kategori keingintahuan dan karakteristik gaya kognitif setiap peserta didik, diharapkan membantu guru dalam membimbing peserta didik untuk mengkonstruksi pemahamannya terhadap konsep matematika sehingga prestasi belajar matematika peserta didik lebih optimal.

\section{METODE PENELITIAN}

\section{Tempat, Waktu, dan Subjek Penelitian}

Penelitian ini dilaksanakan di SMP yang ada di Kabupaten Blora Provinsi Jawa Tengah pada semester ganjil tahun pelajaran 2011/2012. Subjek penelitian ini adalah peserta didik kelas VIII semester ganjil SMP di Kabupaten Blora tahun pelajaran $2011 / 2012$.

\section{Jenis Penelitian}

Jenis penelitian ini adalah penelitian eksperimental semu dengan desain faktorial $2 \times 3 \times 2$

\section{Populasi, Sampel, dan Sampling}

Populasi penelitian ini adalah seluruh peserta didik di 76 SMP di Kabupaten Blora. Sampling dilakukan dengan teknik stratified cluster random sampling sedemikian sehingga diperoleh sampel yang berasal dari SMP sebagai berikut.

a. SMP Negeri 2 Blora dengan kelas VIII 3 sebagai kelas eksperimen satu dan kelas VIII 5 sebagai kelas eksperimen dua.

b. SMP Muhammadiyah 1 Blora dengan kelas VIII B sebagai kelas eksperimen satu dan kelas VIII A sebagai kelas eksperimen dua. 
c. SMP Negeri 1 Cepu dengan kelas VIII B sebagai kelas eksperimen satu dan kelas VIII E sebagai kelas eksperimen dua.

\section{Metode Pengumpulan Data}

Metode pengumpulan data penelitian meliputi metode tes dan angket. Metode tes digunakan untuk memperoleh data kemampuan awal, prestasi belajar matematika, dan gaya kognitif peserta didik. Metode angket digunakan untuk memperoleh data keingintahuan peserta didik.

\section{Teknik Analisis Data}

Sebelum melakukan eksperimen, dilakukan uji keseimbangan terhadap kemampuan awal matematika menggunakan uji-t. Data prestasi belajar matematika dianalisis menggunakan analisis variansi tiga jalan dengan sel tak sama. Sebelumnya, terhadap data kemampuan awal maupun data prestasi belajar dilakukan uji prasyarat meliputi uji normalitas populasi menggunakan metode Lilliefors dan uji homogenitas variansi populasi menggunakan metode Bartlett. Apabila hasil analisis variansi menunjukkan bahwa hipotesis nol ditolak, dilakukan uji komparasi ganda menggunakan metode Scheffe'.

\section{HASIL DAN PEMBAHASAN}

\section{Data Kemampuan Awal Matematika dan Uji Keseimbangan}

Berdasarkan hasil tes kemampuan awal matematika, berikut disajikan deskripsi data kemampuan awal matematika peserta didik.

Tabel 1. Deskripsi Data Kemampuan Awal Matematika Peserta Didik

\begin{tabular}{|c|c|c|c|c|c|}
\hline Kelas & $\boldsymbol{n}$ & Nilai Min & Nilai Maks & $\overline{\boldsymbol{X}}$ & $\boldsymbol{s}$ \\
\hline Eksperimen Satu & 84 & 40 & 96 & 67,5238 & 14,0828 \\
\hline Eksperimen Dua & 84 & 40 & 96 & 66,9524 & 15,0132 \\
\hline
\end{tabular}

Hasil uji prasyarat diperoleh simpulan bahwa sampel berasal dari populasi yang berdistribusi normal dan mempunyai variansi yang homogen. Hasil uji keseimbangan 
menggunakan uji-t diperoleh simpulan bahwa populasi mempunyai kemampuan awal matematika yang seimbang.

\section{Data Penelitian dan Analisis Variansi Tiga Jalan dengan Sel Tak Sama}

Data yang digunakan dalam pengujian hipotesis adalah data prestasi belajar matematika peserta didik pada materi pokok persamaan garis lurus berdasarkan hasil tes pretasi belajar.

Tabel 2. Deskripsi Data Prestasi Belajar Matematika Peserta Didik

\begin{tabular}{|c|c|c|c|c|c|c|c|}
\hline \multicolumn{2}{|c|}{ Keingintahuan } & \multicolumn{2}{|c|}{ Tinggi } & \multicolumn{2}{|c|}{ Sedang } & \multicolumn{2}{|c|}{ Rendah } \\
\hline \multicolumn{2}{|c|}{ Mod. Pemb. } & $F D$ & $F I$ & $F D$ & $F I$ & $F D$ & $F I$ \\
\hline \multirow{5}{*}{$\begin{array}{l}\boldsymbol{N} \\
\boldsymbol{H} \\
\boldsymbol{T}\end{array}$} & $n$ & 12 & 6 & 22 & 18 & 16 & 10 \\
\hline & Nilai Min & 72 & 84 & 48 & 76 & 48 & 52 \\
\hline & Nilai Maks & 100 & 100 & 88 & 100 & 84 & 88 \\
\hline & $\overline{\bar{X}}$ & 91,6667 & 94,6667 & 70,5455 & 88,2222 & 60,5000 & 72,4000 \\
\hline & $s$ & 9,2573 & 7,0048 & 11,7462 & 8,7283 & 10,7207 & 11,6924 \\
\hline \multirow{2}{*}{$S$} & $n$ & 17 & 8 & 27 & 14 & 9 & 9 \\
\hline & Nilai Min & 56 & 60 & 52 & 44 & 56 & 72 \\
\hline$T$ & Nilai Maks & 100 & 100 & 100 & 84 & 80 & 96 \\
\hline \multirow{2}{*}{$\begin{array}{l}A \\
D\end{array}$} & $\overline{\boldsymbol{X}}$ & 76,4706 & 75,0000 & 75,8519 & 64,5714 & 67,1111 & 83,5556 \\
\hline & $s$ & 14,8918 & 15,6753 & 12,6239 & 13,1132 & 7,4237 & 8,3533 \\
\hline
\end{tabular}

Hasil uji prasyarat diperoleh simpulan bahwa sampel berasal dari populasi yang berdistribusi normal dan mempunyai variansi yang homogen. Berikut disajikan hasil analisis variansi tiga jalan dengan sel tak sama.

Tabel 3. Rangkuman Analisis Variansi Tiga Jalan dengan Sel Tak Sama 


\begin{tabular}{|c|c|c|c|c|c|c|}
\hline Sumber & $\boldsymbol{J K}$ & $\boldsymbol{d}$ & $\boldsymbol{R K}$ & $\boldsymbol{F}_{\text {hit }}$ & $\boldsymbol{F}_{\text {tabel }}$ & Keputusan Uji \\
\hline$A$ & 1221,7909 & 1 & 1221,7909 & 9,0843 & 3,9017 & $\mathrm{H}_{0 \mathrm{~A}}$ ditolak \\
\hline$B$ & 4549,2818 & 2 & 2274,6409 & 16,9125 & 3,0540 & $\mathrm{H}_{0 \mathrm{~B}}$ ditolak \\
\hline$C$ & 1279,6692 & 1 & 1279,6692 & 9,5147 & 3,9017 & $\mathrm{H}_{0 \mathrm{C}}$ ditolak \\
\hline$A B$ & 4228,2383 & 2 & 2114,1191 & 15,7190 & 3,0540 & $\mathrm{H}_{0 \mathrm{AB}}$ ditolak \\
\hline$A C$ & 811,5074 & 1 & 811,5074 & 6,0338 & 3,9017 & $\mathrm{H}_{0 \mathrm{AC}}$ ditolak \\
\hline$B C$ & 1191,0764 & 2 & 595,5382 & 4,4280 & 3,0540 & $\mathrm{H}_{0 \mathrm{BC}}$ ditolak \\
\hline$A B C$ & 1754,0724 & 2 & 877,0362 & 6,5210 & 3,0540 & $\mathrm{H}_{0 \mathrm{ABC}}$ ditolak \\
\hline Galat & 20981,1480 & 156 & 134,4945 & - & - & - \\
\hline Total & 36016,7845 & 167 & & & & - \\
\hline
\end{tabular}

\section{Deskripsi Hasil Analisis Variansi Tiga Jalan dengan Sel Tak Sama}

Deskripsi hasil analisis variansi tiga jalan dengan sel tak sama dan uji komparasi rerata adalah sebagai berikut.

a. Prestasi belajar matematika peserta didik yang dikenai model pembelajaran kooperatif tipe NHT lebih baik dibandingkan prestasi belajar matematika peserta didik yang dikenai model pembelajaran kooperatif tipe $S T A D$.

b. Prestasi belajar matematika peserta didik yang memiliki keingintahuan tinggi lebih baik dibandingkan prestasi belajar matematika peserta didik yang memiliki keingintahuan sedang maupun rendah, dan prestasi belajar matematika peserta didik yang memiliki keingintahuan sedang lebih baik dibandingkan prestasi belajar matematika peserta didik yang memiliki keingintahuan rendah.

c. Prestasi belajar matematika peserta didik yang memiliki gaya kognitif field independent lebih baik dibandingkan prestasi belajar matematika peserta didik yang memiliki gaya kognitif field dependent.

d. Terdapat interaksi antara model pembelajaran dan keingintahuan peserta didik, dengan deskripsi sebagai berikut.

1) Pada peserta didik yang dikenai model pembelajaran kooperatif tipe $N H T$, prestasi belajar matematika peserta didik yang memiliki keingintahuan tinggi lebih baik dibandingkan prestasi belajar matematika peserta didik yang memiliki keingintahuan 
sedang maupun rendah, dan prestasi belajar matematika peserta didik yang memiliki keingintahuan sedang lebih baik dibandingkan prestasi belajar matematika peserta didik yang memiliki keingintahuan rendah.

2) Pada peserta didik yang dikenai model pembelajaran kooperatif tipe $S T A D$, prestasi belajar matematika peserta didik yang memiliki keingintahuan tinggi, sedang, maupun rendah sama baiknya.

3) Pada peserta didik yang memiliki keingintahuan tinggi, prestasi belajar matematika peserta didik yang dikenai model pembelajaran kooperatif tipe NHT lebih baik dibandingkan prestasi belajar matematika peserta didik yang dikenai model pembelajaran kooperatif tipe $S T A D$.

4) Pada peserta didik yang memiliki keingintahuan sedang, prestasi belajar matematika peserta didik yang dikenai model pembelajaran kooperatif tipe NHT sama baiknya dengan prestasi belajar matematika peserta didik yang dikenai model pembelajaran kooperatif tipe $S T A D$.

5) Pada peserta didik yang memiliki keingintahuan rendah, prestasi belajar matematika peserta didik yang dikenai model pembelajaran kooperatif tipe NHT sama baiknya dengan prestasi belajar matematika peserta didik yang dikenai model pembelajaran kooperatif tipe $S T A D$.

e. Terdapat interaksi antara model pembelajaran dan gaya kognitif peserta didik, dengan deskripsi sebagai berikut.

1) Pada peserta didik yang dikenai model pembelajaran kooperatif tipe $N H T$, prestasi belajar matematika peserta didik yang memiliki gaya kognitif field independent lebih baik dibandingkan prestasi belajar matematika peserta didik yang memiliki gaya kognitif field dependent.

2) Pada peserta didik yang dikenai model pembelajaran kooperatif tipe $S T A D$, prestasi belajar matematika peserta didik yang memiliki gaya kognitif field independent sama baiknya dengan prestasi belajar matematika peserta didik yang memiliki gaya kognitif field dependent.

3) Pada peserta didik yang memiliki gaya kognitif field dependent, prestasi belajar matematika peserta didik yang dikenai model pembelajaran kooperatif tipe $N H T$ sama baiknya dengan prestasi belajar matematika peserta didik yang dikenai model pembelajaran kooperatif tipe STAD. 
4) Pada peserta didik yang memiliki gaya kognitif field independent, prestasi belajar matematika peserta didik yang dikenai model pembelajaran kooperatif tipe NHT lebih baik dibandingkan prestasi belajar matematika peserta didik yang dikenai model pembelajaran kooperatif tipe $S T A D$.

f. Terdapat interaksi antara keingintahuan dan gaya kognitif peserta didik, dengan deskripsi sebagai berikut.

1) Pada peserta didik yang memiliki keingintahuan tinggi, prestasi belajar matematika peserta didik yang memiliki gaya kognitif field dependent sama baiknya dengan prestasi belajar matematika peserta didik yang memiliki gaya kognitif field independent.

2) Pada peserta didik yang memiliki keingintahuan sedang, prestasi belajar matematika peserta didik yang memiliki gaya kognitif field dependent sama baiknya dengan prestasi belajar matematika peserta didik yang memiliki gaya kognitif field independent.

3) Pada peserta didik yang memiliki keingintahuan rendah, prestasi belajar matematika peserta didik yang memiliki gaya kognitif field independent lebih baik diabndingkan prestasi belajar matematika peserta didik yang memiliki gaya kognitif field dependent.

4) Pada peserta didik yang memiliki gaya kognitif field dependent, prestasi belajar matematika peserta didik yang memiliki keingintahuan tinggi lebih baik dibandingkan prestasi belajar matematika peserta didik yang memiliki keingintahuan sedang maupun rendah, dan prestasi belajar matematika peserta didik yang memiliki keingintahuan sedang lebih baik dibandingkan prestasi belajar matematika peserta didik yang memiliki keingintahuan rendah.

5) Pada peserta didik yang memiliki gaya kognitif field independent, prestasi belajar matematika peserta didik yang memiliki keingintahuan tinggi, sedang, maupun rendah sama baiknya.

g. Terdapat interaksi antara model pembelajaran, keingintahuan, dan gaya kognitif peserta didik, dengan deskripsi sebagai berikut.

1) Pada peserta didik yang dikenai model pembelajaran kooperatif tipe $N H T$, prestasi belajar matematika peserta didik yang memiliki keingintahuan tinggi dan gaya 
kognitif field dependent sama baiknya dengan prestasi belajar matematika peserta didik yang memiliki keingintahuan sedang dan gaya kognitif field independent.

2) Pada peserta didik yang dikenai model pembelajaran kooperatif tipe $N H T$, prestasi belajar matematika peserta didik yang memiliki keingintahuan tinggi dan gaya kognitif field dependent sama baiknya dengan prestasi belajar matematika peserta didik yang memiliki keingintahuan rendah dan gaya kognitif field independent.

3) Pada peserta didik yang dikenai model pembelajaran kooperatif tipe $N H T$, prestasi belajar matematika peserta didik yang memiliki keingintahuan tinggi dan gaya kognitif field independent lebih baik dibandingkan prestasi belajar matematika peserta didik yang memiliki keingintahuan sedang dan gaya kognitif field dependent.

4) Pada peserta didik yang dikenai model pembelajaran kooperatif tipe $N H T$, prestasi belajar matematika peserta didik yang memiliki keingintahuan tinggi dan gaya kognitif field independent lebih baik dibandingkan prestasi belajar matematika peserta didik yang memiliki keingintahuan rendah dan gaya kognitif field dependent.

5) Pada peserta didik yang dikenai model pembelajaran kooperatif tipe $N H T$, prestasi belajar matematika peserta didik yang memiliki keingintahuan sedang dan gaya kognitif field dependent sama baiknya dengan prestasi belajar matematika peserta didik yang memiliki keingintahuan rendah dan gaya kognitif field independent.

6) Pada peserta didik yang dikenai model pembelajaran kooperatif tipe $N H T$, prestasi belajar matematika peserta didik yang memiliki keingintahuan sedang dan gaya kognitif field independent lebih baik dibandingkan prestasi belajar matematika peserta didik yang memiliki keingintahuan rendah dan gaya kognitif field dependent.

7) Pada peserta didik yang dikenai model pembelajaran kooperatif tipe $S T A D$, prestasi belajar matematika peserta didik yang memiliki keingintahuan tinggi dan gaya kognitif field dependent sama baiknya dengan prestasi belajar matematika peserta didik yang memiliki keingintahuan sedang dan gaya kognitif field independent.

8) Pada peserta didik yang dikenai model pembelajaran kooperatif tipe $S T A D$, prestasi belajar matematika peserta didik yang memiliki keingintahuan tinggi dan gaya kognitif field dependent sama baiknya dengan prestasi belajar matematika peserta didik yang memiliki keingintahuan rendah dan gaya kognitif field independent. 
9) Pada peserta didik yang dikenai model pembelajaran kooperatif tipe $S T A D$, prestasi belajar matematika peserta didik yang memiliki keingintahuan tinggi dan gaya kognitif field independent sama baiknya dengan prestasi belajar matematika peserta didik yang memiliki keingintahuan sedang dan gaya kognitif field dependent.

10) Pada peserta didik yang dikenai model pembelajaran kooperatif tipe $S T A D$, prestasi belajar matematika peserta didik yang memiliki keingintahuan tinggi dan gaya kognitif field independent sama baiknya dengan prestasi belajar matematika peserta didik yang memiliki keingintahuan rendah dan gaya kognitif field dependent.

11) Pada peserta didik yang dikenai model pembelajaran kooperatif tipe $S T A D$, prestasi belajar matematika peserta didik yang memiliki keingintahuan sedang dan gaya kognitif field dependent sama baiknya dengan prestasi belajar matematika peserta didik yang memiliki keingintahuan rendah dan gaya kognitif field independent.

12) Pada peserta didik yang dikenai model pembelajaran kooperatif tipe $S T A D$, prestasi belajar matematika peserta didik yang memiliki keingintahuan sedang dan gaya kognitif field independent sama baiknya dengan prestasi belajar matematika peserta didik yang memiliki keingintahuan rendah dan gaya kognitif field dependent.

13) Pada peserta didik yang memiliki keingintahuan tinggi prestasi belajar matematika peserta didik yang dikenai model pembelajaran kooperatif tipe NHT dan memiliki gaya kognitif field dependent sama baiknya dengan prestasi belajar matematika peserta didik yang dikenai model pembelajaran kooperatif tipe STAD dan memiliki gaya kognitif field independent.

14) Pada peserta didik yang memiliki keingintahuan sedang, prestasi belajar matematika peserta didik yang dikenai model pembelajaran kooperatif tipe NHT dan memiliki gaya kognitif field dependent sama baiknya dengan prestasi belajar matematika peserta didik yang dikenai model pembelajaran kooperatif tipe STAD dan memiliki gaya kognitif field independent.

15) Pada peserta didik yang memiliki keingintahuan rendah, prestasi belajar matematika peserta didik yang dikenai model pembelajaran kooperatif tipe STAD dan memiliki gaya kognitif field independent lebih baik dibandingkan prestasi belajar matematika peserta didik yang dikenai model pembelajaran kooperatif tipe $N H T$ dan memiliki gaya kognitif field dependent.

16) Pada peserta didik yang memiliki keingintahuan tinggi, prestasi belajar matematika peserta didik yang dikenai model pembelajaran kooperatif tipe $N H T$ dan memiliki gaya kognitif field independent sama baiknya dengan prestasi belajar matematika peserta didik yang dikenai model pembelajaran kooperatif tipe $S T A D$ dan memiliki gaya kognitif field dependent. 
17) Pada peserta didik yang memiliki keingintahuan sedang, prestasi belajar matematika peserta didik yang dikenai model pembelajaran kooperatif tipe $N H T$ dan memiliki gaya kognitif field independent sama baiknya dengan prestasi belajar matematika peserta didik yang dikenai model pembelajaran kooperatif tipe STAD dan memiliki gaya kognitif field dependent.

18) Pada peserta didik yang memiliki keingintahuan rendah, prestasi belajar matematika peserta didik yang dikenai model pembelajaran kooperatif tipe NHT dan memiliki gaya kognitif field independent sama baiknya dengan prestasi belajar matematika peserta didik yang dikenai model pembelajaran kooperatif tipe STAD dan memiliki gaya kognitif field dependent.

19) Pada peserta didik yang memiliki gaya kognitif field dependent, prestasi belajar matematika peserta didik yang dikenai model pembelajaran kooperatif tipe $N H T$ dan memiliki keingintahuan tinggi sama baiknya dengan prestasi belajar matematika peserta didik yang dikenai model pembelajaran kooperatif tipe $S T A D$ dan memiliki keingintahuan sedang.

20) Pada peserta didik yang memiliki gaya kognitif field dependent, prestasi belajar matematika peserta didik yang dikenai model pembelajaran kooperatif tipe $N H T$ dan memiliki keingintahuan tinggi lebih baik dibandingkan prestasi belajar matematika peserta didik yang dikenai model pembelajaran kooperatif tipe $S T A D$ dan memiliki keingintahuan rendah.

21) Pada peserta didik yang memiliki gaya kognitif field dependent, prestasi belajar matematika peserta didik yang dikenai model pembelajaran kooperatif tipe $N H T$ dan memiliki keingintahuan sedang sama baiknya dengan prestasi belajar matematika peserta didik yang dikenai model pembelajaran kooperatif tipe $S T A D$ dan memiliki keingintahuan tinggi.

22) Pada peserta didik yang memiliki gaya kognitif field dependent, prestasi belajar matematika peserta didik yang dikenai model pembelajaran kooperatif tipe $N H T$ dan memiliki keingintahuan sedang sama baiknya dengan prestasi belajar matematika peserta didik yang dikenai model pembelajaran kooperatif tipe STAD dan memiliki keingintahuan rendah.

23) Pada peserta didik yang memiliki gaya kognitif field dependent, prestasi belajar matematika peserta didik yang dikenai model pembelajaran kooperatif tipe $N H T$ dan memiliki keingintahuan rendah sama baiknya dengan prestasi belajar matematika peserta didik yang dikenai model pembelajaran kooperatif tipe $S T A D$ dan memiliki keingintahuan tinggi.

24) Pada peserta didik yang memiliki gaya kognitif field dependent, prestasi belajar matematika peserta didik yang dikenai model pembelajaran kooperatif tipe $N H T$ dan memiliki keingintahuan rendah sama baiknya dengan prestasi belajar matematika peserta didik yang dikenai model pembelajaran kooperatif tipe STAD dan memiliki keingintahuan sedang.

25) Pada peserta didik yang memiliki gaya kognitif field independent, prestasi belajar matematika peserta didik yang dikenai model pembelajaran kooperatif tipe $N H T$ dan memiliki keingintahuan tinggi lebih baik diobandingkan prestasi belajar matematika peserta 
didik yang dikenai model pembelajaran kooperatif tipe $S T A D$ dan memiliki keingintahuan sedang.

26) Pada peserta didik yang memiliki gaya kognitif field independent, prestasi belajar matematika peserta didik yang dikenai model pembelajaran kooperatif tipe $N H T$ dan memiliki keingintahuan tinggi sama baiknya dengan prestasi belajar matematika peserta didik yang dikenai model pembelajaran kooperatif tipe STAD dan memiliki keingintahuan rendah.

27) Pada peserta didik yang memiliki gaya kognitif field independent, prestasi belajar matematika peserta didik yang dikenai model pembelajaran kooperatif tipe $N H T$ dan memiliki keingintahuan sedang sama baiknya dengan prestasi belajar matematika peserta didik yang dikenai model pembelajaran kooperatif tipe STAD dan memiliki keingintahuan tinggi.

28) Pada peserta didik yang memiliki gaya kognitif field independent, prestasi belajar matematika peserta didik yang dikenai model pembelajaran kooperatif tipe $N H T$ dan memiliki keingintahuan sedang sama baiknya dengan prestasi belajar matematika peserta didik yang dikenai model pembelajaran kooperatif tipe STAD dan memiliki keingintahuan rendah.

29) Pada peserta didik yang memiliki gaya kognitif field independent, prestasi belajar matematika peserta didik yang dikenai model pembelajaran kooperatif tipe $N H T$ dan memiliki keingintahuan rendah sama baiknya dengan prestasi belajar matematika peserta didik yang dikenai model

pembelajaran kooperatif tipe STAD dan memiliki keingintahuan tinggi.

30) Pada peserta didik yang memiliki gaya kognitif field independent, prestasi belajar matematika peserta didik yang dikenai model pembelajaran kooperatif tipe $N H T$ dan memiliki keingintahuan rendah sama baiknya dengan prestasi belajar matematika peserta didik yang dikenai model pembelajaran kooperatif tipe STAD dan memiliki keingintahuan sedang.

31) Pada peserta didik yang dikenai model pembelajaran kooperatif tipe $N H T$ dan memiliki keingintahuan tinggi, prestasi belajar matematika peserta didik yang memiliki gaya kognitif field dependent sama baiknya dengan prestasi belajar matematika peserta didik yang memiliki gaya kognitif field independent.

32) Pada peserta didik yang dikenai model pembelajaran kooperatif tipe $N H T$ dan memiliki keingintahuan sedang, prestasi belajar matematika peserta didik yang memiliki gaya kognitif field independent lebih baik dibandingkan prestasi belajar matematika peserta didik yang memiliki gaya kognitif field dependent. 
33) Pada peserta didik yang dikenai model pembelajaran kooperatif tipe $N H T$ dan memiliki keingintahuan rendah, prestasi belajar matematika peserta didik yang memiliki gaya kognitif field dependent sama baiknya dengan prestasi belajar matematika peserta didik yang memiliki gaya kognitif field independent.

34) Pada peserta didik yang dikenai model pembelajaran kooperatif tipe STAD dan memiliki keingintahuan tinggi, prestasi belajar matematika peserta didik yang memiliki gaya kognitif field dependent sama baiknya dengan prestasi belajar matematika peserta didik yang memiliki gaya kognitif field independent.

35) Pada peserta didik yang dikenai model pembelajaran kooperatif tipe STAD dan memiliki keingintahuan sedang, prestasi belajar matematika peserta didik yang memiliki gaya kognitif field independent sama baiknya dengan prestasi belajar matematika peserta didik yang memiliki gaya kognitif field dependent.

36) Pada peserta didik yang dikenai model pembelajaran kooperatif tipe STAD dan memiliki keingintahuan rendah, prestasi belajar matematika peserta didik yang memiliki gaya kognitif field dependent sama baiknya dengan prestasi belajar matematika peserta didik yang memiliki gaya kognitif field independent.

37) Pada peserta didik yang dikenai model pembelajaran kooperatif tipe $N H T$ dan memiliki gaya kognitif field dependent, prestasi belajar matematika peserta didik yang memiliki keingintahuan tinggi lebih baik dibandingkan prestasi belajar matematika peserta didik yang memiliki keingintahuan sedang maupun rendah, dan prestasi belajar matematika peserta didik yang memiliki keingintahuan sedang sama baiknya dengan prestasi belajar matematika peserta didik yang memiliki keingintahuan rendah.

38) Pada peserta didik yang dikenai model pembelajaran kooperatif tipe NHT dan memiliki gaya kognitif field independent, prestasi belajar matematika peserta didik yang memiliki keingintahuan tinggi, sedang, maupun rendah sama baiknya.

39) Pada peserta didik yang dikenai model pembelajaran kooperatif tipe STAD dan memiliki gaya kognitif field dependent, prestasi belajar matematika peserta didik yang memiliki keingintahuan tinggi, sedang, maupun rendah sama baiknya.

40) Pada peserta didik yang dikenai model pembelajaran kooperatif tipe $S T A D$ dan memiliki gaya kognitif field independent, prestasi belajar matematika peserta didik yang memiliki keingintahuan tinggi, sedang, maupun rendah sama baiknya.

41) Pada peserta didik yang memiliki keingintahuan tinggi dan gaya kognitif field dependent, prestasi belajar matematika peserta didik yang dikenai model pembelajaran kooperatif tipe 
NHT sama baiknya dengan prestasi belajar matematika peserta didik yang dikenai model pembelajaran kooperatif tipe $S T A D$.

42) Pada peserta didik yang memiliki keingintahuan tinggi dan gaya kognitif field independent, prestasi belajar matematika peserta didik yang dikenai model pembelajaran kooperatif tipe NHT sama baiknya dengan prestasi belajar matematika peserta didik yang dikenai model pembelajaran

kooperatif tipe $S T A D$.

43) Pada peserta didik yang memiliki keingintahuan sedang dan gaya kognitif field dependent, prestasi belajar matematika peserta didik yang dikenai model pembelajaran kooperatif tipe NHT sama baiknya dengan prestasi belajar matematika peserta didik yang dikenai model pembelajaran

kooperatif tipe STAD.

44) Pada peserta didik yang memiliki keingintahuan sedang dan gaya kognitif field independent, prestasi belajar matematika peserta didik yang dikenai model pembelajaran kooperatif tipe NHT lebih baik dibandingkan prestasi belajar matematika peserta didik yang dikenai model pembelajaran kooperatif tipe $S T A D$.

45) Pada peserta didik yang memiliki keingintahuan rendah dan gaya kognitif field dependent, prestasi belajar matematika peserta didik yang dikenai model pembelajaran kooperatif tipe NHT sama baiknya dengan prestasi belajar matematika peserta didik yang dikenai model pembelajaran kooperatif tipe $S T A D$.

46) Pada peserta didik yang memiliki keingintahuan rendah dan gaya kognitif field independent, prestasi belajar matematika peserta didik yang dikenai model pembelajaran kooperatif tipe NHT sama baiknya dengan prestasi belajar matematika peserta didik yang dikenai model pembelajaran kooperatif tipe STAD.

\section{PENUTUP}

Berdasarkan analisis data menggunakan analisis variansi tiga jalan dengan sel tak sama, diperoleh simpulan bahwa:

a. Terdapat perbedaan pengaruh antar masing-masing kategori model pembelajaran terhadap prestasi belajar matematika peserta didik.

b. Terdapat perbedaan pengaruh antar masing-masing kategori keingintahuan terhadap prestasi belajar matematika peserta didik.

c. Terdapat perbedaan pengaruh antar masing-masing kategori gaya kognitif terhadap prestasi belajar matematika peserta didik. 
d. Terdapat interaksi antara model pembelajaran dan keingintahuan terhadap prestasi belajar matematika peserta didik.

e. Terdapat interaksi antara model pembelajaran dan gaya kognitif terhadap prestasi belajar matematika peserta didik.

f. Terdapat interaksi antara keingintahuan dan gaya kognitif terhadap prestasi belajar matematika peserta didik.

g. Terdapat interaksi antara model pembelajaran, keingintahuan, dan gaya kognitif terhadap prestasi belajar matematika peserta didik.

\section{DAFTAR PUSTAKA}

Anita Lie. 2008. Mempraktekkan Cooperative Learning di Ruang-ruang Kelas. Jakarta: Grasindo.

Budiyono. 2003. Metodologi Penelitian Pendidikan. Surakarta: Sebelas Maret University Press.

2009. Statistik Untuk Penelitian (Edisi Kedua). Surakarta: Sebelas Maret University Press.

Desmita. 2009. Psikologi Perkembangan Peserta Didik. Bandung: PT. Remaja Rosdakarya.

Nasution, S. 2008. Berbagai Pendekatan dalam Proses Belajar \& Mengajar. Jakarta: PT Bumi Aksara.

Slavin, R. E. 2010. Cooperative Learning: Teori, Riset, dan Praktik. (Edisi terjemahan oleh Narulita Yusron). Bandung: Nusa Media.

Slameto. 2003. Belajar dan Faktor-Faktor yang Mempengaruhinya. Jakarta: PT. Asdi Mahasatya. 
Srivastava, Priyamvada. 1997. Cognitive Style in Educational Perspective. New Delhi: Anmol Publications Pvt Ltd. 